\title{
A Remedial English Course from the Freshmen EFL Learners' Viewpoints and Expectations at the Hashemite University in Jordan
}

\author{
Mohammed M. Obeidat ${ }^{1}$ \\ ${ }^{1}$ Faculty of Educational Sciences, The Hashemite University, Jordan \\ Correspondence: Mohammed M. Obeidat, Faculty of Educational Sciences, The Hashemite University, P.O BOX \\ 330127, Zarqa 13133, Jordan. E-mail: moh.obai29@yahoo.com
}

Received: October 29, 2019

Accepted: November 21, 2019

Online Published: November 23, 2019

doi:10.5430/ijhe.v9n1p89

URL: https://doi.org/10.5430/ijhe.v9n1p89

\begin{abstract}
The higher education system in Jordan requires freshmen students in each university to set for an English aptitude exam. If the student fails in this exam, s/he should register in the remedial English 99 course which is regarded as a prerequisite for English 101. The purpose of this study is to explore students' expectations of this course and whether these expectations are met. The study adopts a qualitative design. Data was collected through a questionnaire interview from 97 students registered in two sections in the Language Center at the university. The findings of the study revealed that students expected the course would improve their communication skills. Later, they discovered that this course benefited them more from the grammatical and structural aspects of language. The findings can be valuable for EFL curriculum developers, syllabus designers and administrators to understand students' needs better and to take their viewpoints into account.
\end{abstract}

Keywords: expectation, freshmen EFL learners, remedial English course, The Hashemite University in Jordan

\section{Introduction}

\subsection{The Aptitude Exam and Remedial Courses}

Every year, many of freshmen EFL learners have to take entrance or aptitude exams in the English language to go on to higher education. This is a mandatory requirement even if the entrant excels at his or her English skills. The reason lies in the fact that more and more non-English speaking universities teach courses using English as the medium (or language) of instruction. However, the primary role of aptitude tests is to predict students' likely performance on a college or university course (McDonald, Newton, Whetton \& Benefield, 2002).

Those who fail the aptitude exam normally have remedial courses in both developed and developing countries. These courses are meant to improve a learning skill or rectify a problem area. The purpose of remedial teaching involves individualized teaching of students who are experiencing difficulties in specific subject areas (Mc Daniel, 2018). In higher education, the remedial courses can help students who are having problems with advanced concepts to fully understand the basics of a subject. Those who learn English as a second or foreign language normally have problems with different areas in the use of language. The learners have to be taken through short or long courses to learn the appropriate use of the language. Normally, students joining college in the Arab nations are given general courses in English while those looking to master the language are taken through basic skill courses (Al Othman \& Shuqair, 2013).

Since English language teaching became a compulsory part of the curriculum in all institutions of higher education in the Arab World, different curricula and methodologies have been experimented to help adult students learn the language effectively, particularly within first-year university preparatory programs. However, despite the huge efforts in aiding the educational process of English as a foreign language (EFL), there is a large turnout of students not meeting the criteria needed to pass their preparatory year (Siddiqui \& Alghamdi, 2017).

\subsection{The Remedial EFL Course in Jordan}

All the students accepted to study at the universities in Jordan should set for the aptitude or level exam in the English language. The students who fail in this exam must register in the Remedial English course (99), which is a prerequisite for English Language 101. Since the target of this current study is the student who has just had Remedial 
English (99), let us state its course description. That is, the aim of this course is to educate the students to pass this compulsory course. It provides them with the basic preparatory grammatical rules and structures for English Language 101. The material focuses primarily on structures, reading comprehension and vocabulary. The textbook adopted to achieve the aim of this course is New Headway Plus published by Oxford. The objectives of this course are related to structures, reading comprehension and vocabulary. With regard to grammar and structure, the objectives are: (1) introducing the basic English rules for present, past and future tenses, (2) formatting and answering the Yes/No and Wh questions, (3) acquainting the students with the expressions of quantity, the articles $a$ and the and with the verb patterns. In terms of reading comprehension, the objective is introducing the students with the main reading skills that help them answering comprehension questions in an effective way. As for vocabulary, the main objective is providing the students with the relevant vocabulary words stated by the end of each unit along with their English and Arabic meaning.

However, learners' perceptions may sometimes override language teachers' approach when they are totally ignored. Learners' attitude is one of the key stones of language learning (Al-Jamal \& Al-Jamal, 2014). A thorough understanding of students' expectation when they first enroll at university may benefit language education and increase success in teaching (LandolfI, 2014). As stated: "we're big on student voice at Noble Impact. Students are the key constituents of the education system, so it only makes sense to include them in the conversation about their education" (Swallow, 2016: 1). Therefore, this current study attempts to give more weight to students' aspirations and viewpoints with respect to the EFL courses they have, particularly during the preparatory year or during the first year of their university study. The aim is to fill a gap in the literature related to remedial EFL course and to resolve the problem stated below.

\subsection{Problem of the Study}

Many studies were conducted on the effectiveness of EFL remedial courses in developing countries and the majority aimed to investigate or even to decide upon whether these courses are effective. A few of these studies attempted to explore EFL learners' expectations of the courses and whether these expectations are met. Therefore, the present study has come to the scene to make up for the drawbacks of the related studies so that it can shed light on the linguistic aspects the students emphasized and de-emphasized in terms of both expectation and reality.

\subsection{The Purpose and Questions of the Study}

The purpose of this study is to explore newly admitted students' expectations of the Remedial English course 99 held for those who fail in the English aptitude exam at the Hashemite University in Jordan. The study also aims to investigate whether these expectations are met. All in all, the study attempts to answer the following two main questions:

A) What are the students' expectations of the benefit they get from Remedial English 99?

B) Have the students' expectations been met by the end course?

\section{Review of Related Studies}

Personal experience and the results of studies conducted on this area (e.g., Al Othman \& Shugair, 2013, \& Onditi, 2014) have revealed that the effectiveness of remedial teaching of students in their EFL/ESL studies varies. Some of the courses developed for remedy achieved their aim and others did not.

Nasser and Kfouri (2008) investigated whether remedial courses in a private university in Lebanon affect the enrolment decision of pre-admission students. They also investigated the effectiveness of the remedial English courses or subsequent English and academic performance. Findings revealed that the remedial courses were not effective in providing better performance on general academic subjects. They also showed that a large number of remedial placement discouraged students from enrolling in the university.

Al Othman and Shugair (2013) looked into evidence presented by other researchers about the effectiveness of remedial courses. The research material used was mainly secondary. Through a comprehensive exploration of the information from various researchers, the paper had presented those researchers' findings. The research findings showed that the remedial courses in the Arab universities had been ineffective in increasing English language skills of students learning EFL/ESL.

Cheng (2014) conducted a study whose aim was to deepen understanding of how remedial teaching transformed low achievers' learning outcomes in English and how low achievers gained control over learning English. The study involved 42 semi-structured interviews with the students, the instructor, and the class mentor at two phases over a period of 10 months. The results suggested that remedial teaching was beneficial to the students' academic and 
emotional perceived self-efficacy. The study emphasized that individual remedy teaching, direct supervision from teachers, and an appropriate support system led to better academic and emotional self-efficacy.

Onditi (2014) examined the effect of a remedial English course in raising the level of English proficiency of freshmen at the United States International University. The study tracked 46 underprepared students admitted to (USIU) who failed to make the threshold for university course in a placement test (pretest) and went through a remedial English course for 14 weeks. On completion of the course, they were given the same placement test (posttest). Comparison between the scores in the pretest and those on the posttest showed that the remedial course raised the students' English proficiency.

Armagan, Bozoglu and Guven (2016) explored what students expected from EFL classes and overall language education provided in two higher education level preparatory schools and to what extent their expectations were met. The study was in qualitative case study design. Data was collected through a web-based questionnaire from 218 preparatory school students in two higher education departments. The thematic analysis of the data revealed that the main areas where students expected improvement and change were curricula content and the physical layout of the building. On the other hand, the students' expectations from academic staff seemed to have been met considerably.

Alghamdi and Siddiqui (2016) investigated an institutionalized remedial approach held by an English language institute at a Saudi university in order to support foundation year struggling students who often achieved low grades or failed to pass a certain level of the English language program. The study utilized semi-structured interviews to address three issues: (1) Screening for low-achieving learners, (2) Remedial sessions' procedure and significance, and (3) Learning' attitudes and conduct during remedial sessions. Thematic analysis of interviews showed that time limitation and lack of logical structure lowered the effectiveness of remedial sessions in terms of numbers of supported learners and the remedial procedure itself. It was also found that low-achieving learners were rarely referred to by their teachers, but instead came on their own to seek support.

Siddiqui and Alghamdi (2017) explored differential instruction (DI) in EFL remedial classes in Saudi Arabia. They hypothesized that students would benefit from the varied instruction, modified materials and flexible grouping within the class setup. Qualitative data was collected in the form of grading of a pretest and posttest. The differences in the results of the two sets of tests showed positive impact of implementing DI on learning, and were found to be statistically significant.

Jimenez (2018) reported the final findings of an explanatory, descriptive case study that aimed at exploring the perceptions of a group of EFL students in a public university regarding their English learning and the commitment level through the process. A questionnaire, a survey, and the teacher's diary were the instruments used to gather data. The results indicated the way the participants studied and learned English, their most common learning styles, and studying strategies. Additionally, they showed some students' low levels of commitment and autonomy, and some indifference as regards English, too.

It is apparent from the literature above that the majority of studies done in non-native English speaking countries showed that the remedial EFL courses utilized in the universities were ineffective. Other studies revealed that these courses were effective. Since the remedial EFL courses are common in almost all higher education systems, the researcher has found it necessary to conduct this study, which aims to examine students' expectations of the remedial English course 99 and whether this course achieved its aims according to their views.

\section{Methods}

A qualitative case study approach was employed to explore student expectations and beliefs regarding the Remedial English course (99) adopted in the Hashemite University and in higher education as a whole and the extent to which these expectations are met. Due to the problems in English language education in the basic education stage and in the secondary cycle in the country, remedial English is seen as an opportunity to learn English with an intensive course given during the first semester of their study at the university. Therefore, the cases in this study can help policymakers, syllabus designers, researchers and practitioners to gain insight into adult learners' needs and expectations regarding this issue.

\subsection{The Setting and Participants of the Study}

This research was conducted in the Language Center at the Hashemite University. The students who failed to get the required passing grade in the English language aptitude exam had to have Remedial English 99 during the first semester of their study. These students were the participants of the study. The total number of students was 145 . For the study, students registered in two sections were selected. In total, 97 students were included. 


\subsection{Data Collection and Analysis}

Data was collected through two open-ended questions in a pre-and post-surveys. The first question was asked at the beginning of the course and the second was asked by the end of it. The students were requested to answer these questions either in English or Arabic. However, the two open-ended questions are: (1. Could you please describe your expectations of the benefits you may get from studying Remedial English 99? 2. Now, what are the aspects of language you have benefited from English 99 and made you feel of improvement during the course?). The data were analyzed through the use of inductive analysis. That is, the researcher examined the responses thoroughly and in detail and categorized them into linguistic themes. Each response was quoted next to the theme determined in advance. The themes were counted and supported by relevant quotations. Finally, these themes were given percentages according to the total number of times each one occurs.

\section{Results}

\subsection{Results Related to the First Research Question}

It is noteworthy that the first research question is answered through the first open-ended question Could you please describe your expectations at the beginning of the semester of the benefits you may get from studying Remedial English 99? The analysis of students' responses to this question led to four linguistic themes, which are: language skill and communication, grammar and written structures, vocabulary, and reading comprehension. These themes are presented in Table 1. with their frequency and percentage of occurrence. The themes and the sum of responses or expectations are also presented in Table 2.

Table 1. Students' expectations of the benefits from Remedial English 99

\begin{tabular}{ccc}
\hline Language aspect & Frequency & Percentage \\
\hline Language skills and & 46 & 59 \\
communication & 17 & 21 \\
Grammar & 9 & 11 \\
Vocabulary & 7 & 9 \\
Reading comprehension & &
\end{tabular}

4.1.1 Language Skill and Communication

One fundamental finding of the study is that over half (59) of the total number of respondents $(\mathrm{N}=79)$ focused on the skills of language and communication. That is, the students expected that the Remedial English 99 course might help them develop their language skills and their communication competence as a whole. Some of the respondents focused on the oral skills. They expected that this course might give them the chance to participate during class times and to be acquainted with the teacher's talk in the English language. Below are illustrative examples of students' responses.

I want English 99 to help me give and take in English if the teacher gives me the chance to discuss with him in English.

There is a lot of discussion during lectures. I expect that this subject will encourage me to discuss and speak.

I expect that it will develop my speaking and listening skills because the teacher speaks only English from the first lecture.

Some respondents focused in their expectations on the academic skills. They regarded these skills as an important requirement for exams: see the examples below.

I expect that this subject will enable me to write in English well. I am afraid of my teachers' questions.

I hope this subject will help me read and write well to understand better and to write correct English.

Other respondents emphasized both oral and academic skills in their expectations. One of them thought that these skills would help him or her participate during lectures and pass his or her exams: see the examples below.

Nobody knows. I hope that English 99 can help me to listen, speak and write in English.

I expect that this subject will develop my speaking and writing skills to participate during lectures and answer questions with good language.

I expect that this Subject and English 101 will develop my speaking, writing and reading skills. 
Finally, some respondents expected that the course might develop their communication skills as a whole, which would help them increase their participation in the class from their viewpoint as illustrated in the examples below.

I expect that English 99 may give me the chance to communicate in the English language with my teachers.

I want to communicate in English to be able to participate in the classes.

What I want from the university is to develop my communication skills in English. I hope that English 99 will develop them.

\subsubsection{Grammar}

Seventeen of the respondents to this question expected that the Remedial English 99 course would develop their grammatical competence in the English language. Some of them highlighted their weakness in this language aspect at school and wanted the course to empower them with the necessities to pass the exams in their subject areas. Below are illustrative examples.

MY problem is grammar. I expect that it will develop the grammar of language for my answers to be correct.

I expect that English 99 may deepen my understanding of grammar because the exams in my specialization will be subjective.

I expect that this subject may help me improve my grammar of English to compensate for this weakness in the school.

I want the teacher to make me understand the way in which sentences are written correctly. My weakness is the tense of the sentence. I want to know more about the tenses.

Some of the respondents focused on the verb tense and expected the course to develop their knowledge in this grammatical aspect: see the examples below.

I do not know. I expect that this subject may develop the tenses of language.

I hope that this subject will develop my knowledge of the tenses, particularly past perfect, present perfect and continuous.

One of the respondents stated that he was in need of the way questions and answers are formulated. Therefore, he expected the course to achieve that for improving his performance during exams. The examples below illustrates this.

I expect that English 99 may acquaint me with the way questions are asked and answered, particularly during exams.

\subsubsection{Vocabulary}

Nine of the respondents expected that English 99 would enrich them with the words and idioms necessary for understanding their subject areas, particularly the scientific ones: see the examples below.

I expect that English 99 will develop my vocabulary repertoire to go along with the requirements of my specialization.

Vocabulary (words) are important for my specialization. I hope that English 99 will provide me with scientific reading passages to enrich my vocabulary.

I expect to benefit from the scientific reading texts to enrich my vocabulary in chemistry.

Some of the respondents expected that the course would enrich them with more and more words and/or idioms in the target language in general. As they state:

This subject is full of new vocabulary. I expect that it will increase my vocabulary words.

This is a good question. I expect that this subject may enrich my words in English.

My expectation is that English 99 may increase my vocabulary and idioms in English.

4.1.4 Reading Comprehension

A total of seven respondents reported that Remedial English 99 would help them improve their reading comprehend in English which would help them in their specializations. As they stated:

I expect this subject will help me to read English well and understand my subjects in my IT specialization.

I expect it to help me read quickly and understand any lesson in my specialization. 
On the other hand, the other four declared they suffered a lot from understanding the reading passages and the questions included in the exams, particularly those stated in the aptitude exam. Therefore, they hoped Remedial English 99 would develop their comprehension of these passages and questions: see illustrative examples below.

I hope English 99 will help me read and understand at least the questions.

I suffered from answering the questions of the reading passages during the aptitude exam. I hope that English 99 will develop that.

I expect that English 99 may help develop my reading comprehension skill. My failure in the aptitude exam was because of the reading passage and their questions.

Yesterday, we had a reading passage. I respect the way the teacher asked questions on it. She trained us on how to find inferential questions. I expect this subject may be effective in developing my ability to answer teachers' questions.

Table 2. Students' expectations of the benefits they may get from Remedial English 99

\begin{tabular}{|c|c|}
\hline No. & Category \\
\hline 1. & $\begin{array}{l}\text { Language skills } \\
\text { and communication }\end{array}$ \\
\hline 2. & Vocabulary \\
\hline 3. & $\begin{array}{l}\text { Language skills and } \\
\text { communication }\end{array}$ \\
\hline 4. & Grammar \\
\hline 5. & $\begin{array}{c}\text { Reading } \\
\text { comprehension }\end{array}$ \\
\hline 6. & $\begin{array}{l}\text { Language skills } \\
\text { and communication }\end{array}$ \\
\hline 7. & \\
\hline 8. & Grammar \\
\hline 9 & $\begin{array}{c}\text { Reading } \\
\text { comprehension }\end{array}$ \\
\hline 10. & $\begin{array}{c}\text { Language skills } \\
\text { and communication }\end{array}$ \\
\hline 11. & $\begin{array}{l}\text { Language skills } \\
\text { and communication }\end{array}$ \\
\hline 12. & $\begin{array}{c}\text { Language skills } \\
\text { and communication }\end{array}$ \\
\hline 13. & $\begin{array}{l}\text { Language skills } \\
\text { and communication }\end{array}$ \\
\hline 14. & $\begin{array}{l}\text { Language skills } \\
\text { and communication }\end{array}$ \\
\hline 15. & $\begin{array}{l}\text { Language skills } \\
\text { and communication }\end{array}$ \\
\hline
\end{tabular}

I expect this subject that it will develop my vocabulary because I could not understand the sentences provided in the aptitude exam.

I want English 99 to help me give and take in English if the teacher gives me the chance to discuss with him in English.

I hope that English 99 will improve my grammar in English.

I expect this subject will help me to read English well and understand my subjects in my IT specialization.

I expect that English 99 will give me the chance to communicate in the English language with my teachers.

I do not know. I expect it will develop my language.

MY problem is grammar. I expect that it will develop the grammar of language for my answers to be correct.

I expect it to help me read quickly and understand any lesson in my specialization.

I expect the teacher will give me the chance to communicate without focusing on mistakes.

The important thing is the language skills which help me in my subjects.

I expect that this subject may help me write quickly after the teacher.

I expect it to improve my level in writing because my teachers told that there would be no objective tests in this specializations and they need clear and correct answers from the students.

Nobody knows. I hope that English 99 can help me to listen, speak and write in English.

My teacher from the very beginning speaks in English quickly. I think this may help me follow the lectures well. 
16. Reading comprehension

17. Grammar

18. Language skills and communication

19. Language skills and communication

20. Grammar

21. Vocabulary

22. Language skills and communication

23. Language skills and communication

24. Grammar

25. Language skills and communication

26. Grammar and written structures

27.

28.

Reading comprehension

Language skills and communication

29.

Grammar

30.

31.

32.

33.

34.

Language skills and communication

35.

Language skills and communication

36. Language skills and communication

37.

Grammar

38.

Language skills and communication

39. Vocabulary

40. Language skills and
I hope English 99 will help me read and understand at least the questions.

I do not know. I expect that this subject may develop the tenses of language.

I expect that it will develop my speaking and listening skills because the teacher speaks only English from the first lecture.

I try to listen to the teacher and understand her well. I expect the main thing I will benefit is listening.

It seems from the beginning of the semester that the subject focuses on grammar. I expect that it will develop my grammar.

This subject is full of new vocabulary. I expect that it will enrich my vocabulary.

I expect that English 99 will give me the chance to speak in English and to communicate in it.

I expect that this subject may help me understand my teachers and answer their questions very quickly.

I cannot predict the benefits, but I hope it will improve my grammar during exams. That is all I can say.

I want to communicate in English to be able to participate in the classes.

I hope that this subject will develop my knowledge of the tenses, particularly past perfect, present perfect and continuous.

I suffered from answering the questions of the reading passages during the aptitude exam. I hope that English 99 will develop that.

I think that English 99 will develop my language as a whole to participate in the classes effectively.

I expect that this subject can develop the structure of my language to be able write well in English.

I do not know. I have not yet started seriously.

I was trembling during the aptitude exam. I could not read even the questions. I hope that English 99 will help me to read with comprehension.

I do not Know.

I expect to benefit from the scientific reading texts to enrich my vocabulary in chemistry.

I expect that English 99 may develop my ability to communicate in the English language with my Geology teachers.

I hope that English 99 will develop my listening skill because the teacher always speaks during the lecture.

I expect that this subject will develop my speaking and writing skills to participate during lectures and answer questions with good language.

I cannot predict, but I hope to improve my grammar in the English language. My result in English in the Tawjihi Exam was poor because of grammar.

I expect that this Subject and English 101 will develop my speaking, writing and reading skills.

Frankly speaking, I am bored of English. I hope it will develop my vocabulary and that is it.

My English is good. What I need is communication. 
communication

41.

$$
\text { Vocabulary }
$$

Language skills and communication

43.

Reading comprehension

44.

Language skills and communication

45.

46.

47. Language skills and communication

48. Grammar

49.

50. Language skills and communication

51.

Language skills and communication

52.

Grammar

53.

Language skills and communication

54.

$$
\text { Vocabulary }
$$

55.

Language skills and communication

56.

Language skills and communication

57.

58.

59.

Language skills and communication

60.

Language skills and communication

61.

62.

63.
I expect that English 99 will develop my vocabulary repertoire to go along with the requirements of my specialization.

It seems that the teacher's way of teaching is relaxing. I expect that she will give us the chance to speak with relaxation.

I expect that English 99 may help develop my reading comprehension skill. My failure in the aptitude exam was because of the reading passage and their questions.

What I want from the university is to develop my communication skills in English. I hope that English 99 will develop them.

I cannot answer this question.

I failed in the aptitude exam. I expect that I will fail in English 99.

To speak in English because speaking is the most important.

I expect that English 99 will remind me of all the grammar given in the school.

No comment.

I hope that this subject will benefit me in reading, writing and speaking.

My teachers are speaking quickly, they are writing on the board quickly and reading quickly. Therefore, I need this subject to train me on these skills.

I want the teacher to make me understand the way in which sentences are written correctly. My weakness is the tense of the sentence. I want to know more about the tenses.

People say that the teachers at the university are better in English. I will hear a lot and speak a lot during lectures. I expect that English 99 may develop the habit

(skill) of listening and speaking.

Vocabulary is important in my specialization. I hope that English 99 will provide me with scientific reading passages to enrich my vocabulary.

The teacher told the students that some lessons will be given in the lab in order for the students to listen to English or American people. I expect these lessons may acquaint me to listen to native speakers.

It seems from the first week of the semester that the students have the freedom to communicate with the teacher and with my colleagues. I expect this subject will enable me to speak in English.

I cannot expect anything from the beginning.

Let me see what it will happen during the semester.

What is my expectation? I expect that this subject may develop my habit of listening to the teachers during the semester.

My teachers in the faculty want the students to communicate with them in English even in their offices in the Department of Tourism. I hope that the teacher in this subject will encourage us to communicate in English.

\section{I cannot predict.}

I expect that English 99 may deepen my understanding of grammar in English because the exams in my specialization will be subjective.

Let me speak in English. 


$\begin{array}{cc}\text { 64. } & \text { Vocabulary } \\ 65 . & \begin{array}{c}\text { Language skills and } \\ \text { communication }\end{array} \\ 66 . & \text { Grammar } \\ 67 . & \\ 68 . & \begin{array}{c}\text { Language skills and } \\ \text { communication }\end{array} \\ 69 . & \\ 70 . & \begin{array}{c}\text { Language skills and } \\ \text { communication }\end{array} \\ 71 . & \begin{array}{c}\text { Language skills and } \\ \text { communication }\end{array} \\ 72 . & \text { Reading } \\ 7 & \text { comprehension }\end{array}$

73.

74. Language skills and communication

75. Vocabulary

76. Language skills and communication

77. Grammar

78.

79. Language skills and communication

80.

81. Vocabulary

82. Grammar

83. Language skills and communication

84.

85. Language skills and communication

86. Language skills and communication

87. Grammar

88. Language skills and communication

89.
I expect English 99 will enrich my language with new vocabulary because they are very many.

I want this subject to help me speak English quickly.

I expect that English 99 may deepen my understanding of grammar.

I expect this subject will develop my language as a whole. Let us see. No specific answer can be given now.

My expectation is that English 99 will develop my listening kill because the teacher is always speaking in English.

No answer

I hope that English 99 will cause me to speak English like native speakers. I like English.

I expect that English 99 will develop my skill of writing and speaking because the university focuses on these skills.

Yesterday, we had a reading passage. I respect the way the teacher asked questions on it. She trained us on how to find inferential questions. I expect this subject may be effective in developing my ability to answer teachers' questions.

I could not grasp what the student meant by his/her answer.

I expect that this subject will enable me to write in English well. I am afraid of my teachers' questions.

My expectation is that English 99 may increase my vocabulary and idioms in English.

There is a lot of discussion during lectures. I expect that this subject will encourage me to discuss and speak.

I expect English 99 will improve my grammar in the language. It seems the matter in my specialization needs clear language to be written to teachers.

No answer

My English is good. I hope that English 99 will develop my ability to communicate in English to pursue my study in nursing easily.

My expectations! I am not a magician.

This is a good question. I expect that this subject may increase my words in English.

My expectation is that English 99 may help me use grammatically correct sentences since the focus of this unit is on grammar.

I expect this subject may develop my speaking and listening skills with the help of the lab.

No answer....only lines drawn on the paper

I hope this subject will help me read and write well.

I expect that English 99 may help me communicate with my teachers during lectures to prove that I am a capable student.

I expect that this subject may help me improve my grammar of English to compensate for this weakness in the school.

My expectation is that English 99 may help me listen, speak and write better in English.

I expect...I expect! 
90. Language skills and communication

91. Grammar

92.

93. Language skills and communication

94. Grammar

95. Language skills and communication

96.

Language skills and communication
I expect English 99 may help me to interact in English well so that I can interact with my teachers and colleagues successfully.

I expect that this subject may make me understand better the constituents of the sentence in English.

No answer

My expectations are good from this subject. I expect that English 99 to communicate in English better and to speak eloquently.

I expect that English 99 may improve my grammar in English.

I hope that this subject will develop my ability to follow the lectures in the IT department.

I expect that English 99 may encourage me to speak in English because my teacher is relaxing.

97.

No answer

\subsection{Results Related to the Second Research Questions}

The analysis of students' responses to the second research question was conducted through the analysis of their responses to the second open-ended question: what are the aspects of language you have benefited from English 99 and made you feel of improvement during the course?. This analysis led to the same four linguistic themes, including grammar and written structures, language skills and communication, reading comprehension, and vocabulary. The main difference lies in the fact that the students benefited more from grammar and reading comprehension. In addition, written structures were added to grammar since both are interrelated in any language. However, the table below shows the linguistic themes ordered decreasingly according to their frequency and percentage of occurrence. The themes and the sum of responses related the benefits of the course are also presented in table 4

Table 3. The aspects of language the students think they benefited from English 99

\begin{tabular}{ccc}
\hline Language aspect & Frequency & Percentage \\
\hline Grammar and written & 34 & 39 \\
structures & & \\
Language skills and & 22 & 25 \\
communication & 17 & 19 \\
Reading comprehension & 15 & 17 \\
Vocabulary & & \\
\hline
\end{tabular}

\subsubsection{Grammar and Written Structures}

Findings indicate that over half of the total number of responses (78) to this question emphasized that grammar and written structures were the most beneficial. Through 38\% of these responses, students thought that English 99 benefited them in both grammatical and structural aspects, which are associated with verb tenses, question forms, articles and expressions of quantity and quality. Each stated the benefit(s) from his or her angle depending on his or her need. It is noteworthy in this regard that the majority of respondents thought that they benefited a lot from the tenses, such as present progressive, past progressive, past perfect and future: as stated in the examples below.

Really, I benefited from the past perfect tenses and articles.

The present progressive and past progressive tenses and forming Yes/No questions.

I benefited from the use of progressive verbs, future verbs and from the articles the and $a$.

Question tag questions, how to ask Yes/No questions, the way the indefinite article a is used, and the past perfect.

I benefited from the expressions of quantity and from the tenses.

\subsubsection{Language Skills and Communication}

Twenty-two of the responses to this question highlighted the sources of benefit with regard to this linguistic theme. Some of the respondents thought that the lab was the only source of benefit. They stated that the dialogues, which took place between native speakers of English, gave them the chance to listen to what they said and helped them to grasp the way in which they talked to each other: see the examples below. 
I benefited a lot from the lessons given in the lab. This gives me the chance to grasp the way native speakers of English communicate.

From some lessons given through the lab, listening how native speakers of English converse between each other.

Everything is not new to me. The only thing I feel I benefited from is the lab and the dialogues which took place between people.

Some respondents thought that the teacher was the only source of benefit. They admired him or her because s/he is a native-like in the target language as illustrated in the examples below.

The teacher was very good. Her way of speech in English was like the native speaker's. I listened well to her and I tried to imitate her.

Nearly Everything is new to me, but I benefited from my teacher's way of speech in English and this helps me to understand my teachers during lectures in the department.

Other respondents thought that they benefited from both the lab and the teacher. They benefited from their accent and their way of speech as it is clear in the following examples.

I benefited from listening to my teacher speaking good English and from the lab. From some lessons given through the lab, listening how native speakers of English converse each other.

I benefited from listening to my teachers speaking good English and from the lab.

\subsubsection{Reading Comprehension}

Seventeen of the respondents to this question declared that they benefited a lot from the reading passages included in the content of English 99. Some stated that these passages improved their reading comprehension skills: see the examples below.

The reading passages are fantastic. They helped me improve my reading skill and comprehension in the English language.

I benefited from the reading passages. I am familiarized with reading with understanding.

Other respondents stated that the topics of the reading passages encompassed in the target subject aided them to understand the reading texts, which would help them in their specializations.

I benefited from the reading passages a lot in terms of topic. I am now familiarized with reading any passage quickly.

I benefited from the reading passages. I am now ready to read any text in Geology.

Other respondents stated that the questions located below reading passages and the vocabulary words included in each helped them understand better these passages as illustrated below.

I benefited from the reading passages and from the questions below them. This helped me to read passages and understand them.

I benefited from reading comprehension passages. The vocabulary of these passages helped a lot to understand them.

I benefited from the reading passages and from their vocabulary.

Finally, one of the respondents thought that the factor which improved her skill of reading is the time given by the teacher to answer questions: see the illustrative example below.

I benefited from the reading passages and from the time given to answer questions. This familiarized me to read quickly with understanding.

\subsubsection{Vocabulary}

Fifteen of the respondents argued that they benefited from the new words provided in the content of the target course.

Some of these respondents declared that they benefited from the words included in reading passages and provided in each lesson as illustrative below.

I benefited from the vocabulary included in the reading passages and their pronunciation.

I benefited from the reading passages and from their vocabulary.

I benefited from some of the words mentioned in the reading passage, particularly the scientific words. 
I benefited from the vocabulary words provided in each lesson...

Other respondents declared that they benefited from the words listed in the end of each unit. As two of them stated:

I benefited a lot from the list of vocabulary words located in the end of each unit.

I benefited from some of the new vocabulary located in the end of each unit.

Table 4. The aspects of language the students think they benefited from English 99

\begin{tabular}{|c|c|c|}
\hline No. & Category & Response \\
\hline 1. & $\begin{array}{l}\text { Grammar and written } \\
\text { structures }\end{array}$ & $\begin{array}{c}\text { The present progressive and past progressive tenses and forming Yes/No } \\
\text { questions. }\end{array}$ \\
\hline 2. & $\begin{array}{l}\text { Grammar and written } \\
\text { structures }\end{array}$ & Really, I benefited from the articles and past perfect. \\
\hline 3. & Vocabulary & $\begin{array}{c}\text { I benefited from the vocabulary included in the reading passages and their } \\
\text { pronunciation. }\end{array}$ \\
\hline 4. & $\begin{array}{l}\text { Language skills and } \\
\text { communication }\end{array}$ & I benefited from the dialogues between native speakers in the lab. \\
\hline 5. & $\begin{array}{l}\text { Reading } \\
\text { comprehension }\end{array}$ & $\begin{array}{l}\text { I benefited from the reading passages and from the questions below them. This } \\
\text { helped me to read passages and understand them. }\end{array}$ \\
\hline 6. & & I did not benefited from English 99. \\
\hline 7. & $\begin{array}{l}\text { Grammar and written } \\
\text { structures }\end{array}$ & I benefited from the verb patterns, past perfect and present perfect. \\
\hline 8. & $\begin{array}{l}\text { Language skills and } \\
\text { communication }\end{array}$ & $\begin{array}{l}\text { I benefited from listening to my teachers speaking good English and from the } \\
\text { lab. }\end{array}$ \\
\hline 9. & $\begin{array}{l}\text { Grammar and written } \\
\text { structures }\end{array}$ & I benefited from the expressions of quantity and the tenses. \\
\hline 10. & $\begin{array}{l}\text { Reading } \\
\text { comprehension }\end{array}$ & I am not sure, but I can say that the reading passages are the most useful. \\
\hline 11. & $\begin{array}{l}\text { Language skills and } \\
\text { communication }\end{array}$ & $\begin{array}{c}\text { From some lessons given through the lab, listening how native speakers of } \\
\text { English converse between each other. }\end{array}$ \\
\hline & Vocabulary & \\
\hline 12. & $\begin{array}{c}\& \\
\text { Reading } \\
\text { comprehension }\end{array}$ & $\begin{array}{l}\text { I benefited from the vocabulary words provided in each lesson and I understood } \\
\text { the reading passages through the recognition of these words. }\end{array}$ \\
\hline 13. & $\begin{array}{l}\text { Grammar and written } \\
\text { expression }\end{array}$ & I benefited from the articles and from the tenses. \\
\hline 14. & & The subject was not useful. \\
\hline 15. & $\begin{array}{l}\text { Language skills and } \\
\text { communication }\end{array}$ & $\begin{array}{l}\text { I benefited from the teacher and some students speaking English fluently. I tried } \\
\text { to imitate them, but I still need time to become a good speaker. }\end{array}$ \\
\hline 16. & $\begin{array}{l}\text { Grammar and written } \\
\text { structures }\end{array}$ & I benefited from the irregular verbs and from the use of articles in sentences. \\
\hline 17. & $\begin{array}{c}\text { Reading } \\
\text { comprehension }\end{array}$ & $\begin{array}{l}\text { I benefited from the reading passages. I am now ready to read any text in } \\
\text { Geology. }\end{array}$ \\
\hline \multirow{3}{*}{18.} & $\begin{array}{c}\text { Reading } \\
\text { comprehension }\end{array}$ & \multirow{3}{*}{$\begin{array}{l}\text { I benefited from many things in this subject: reading passages, vocabulary and } \\
\text { the tenses. }\end{array}$} \\
\hline & $\begin{array}{c}\text { vs } \\
\text { Vocabulary }\end{array}$ & \\
\hline & vs & \\
\hline Publis & by Sciedu Press & ISSN 1927-6044 E-ISSN 1927-6052 \\
\hline
\end{tabular}


Grammar

19. 20. Language skills and
communication

21. Grammar and written structures

22. Language skills and communication

$23 . \quad$ Reading comprehension

Grammar

24.

$$
\mathrm{Vs}
$$

Vocabulary

25.

26.

Language skills and communication

Grammar and written structures

27.

Vs

Vocabulary

28. Vocabulary

29. Language skills and communication

30.

31. Grammar and written structures

32. Grammar and written structures

33. Language skills and communication

34.

35. Grammar and written structures

36. Vocabulary

37. Grammar and written structures

38. Language skills and communication
I benefited from the expressions of quantity and from the tenses.

Nearly Everything is new to me, but I benefited from my teacher's way of speech in English and this helps me to understand my teachers during lectures in the department.

I benefited from the way sentences and questions are formed.

I benefited mainly from the lab.

The reading passages are fantastic. They helped me to improve my reading skill and comprehension in the English language.

I benefited from the tenses, irregular verbs and vocabulary.

I am bored, I do not know.

I was interested in listening to my teacher speaking English and I liked to speak to her.

Everything: grammar, questions, articles and vocabulary.

I benefited a lot from the list of vocabulary words located by the end of each unit.

Everything is not new to me. The only thing I feel I benefited from is the lab and the dialogues which took place between people.

No answer

The tenses and the expressions of quantity and quality.

Forming and answering wh-questions, present progressive and past progressive.

I benefited a lot from the lessons given in the lab. This gives me the chance to grasp the way native speakers of English communicate.

I did not benefit anything from this subject. It is just repetition.

I benefited a lot from forming questions and from the tenses.

I benefited from the idioms, expressions and the vocabulary included in the reading passaged allotted to scientific issues.

I benefited from the use of progressive verbs, future verbs and from the articles the and $a$.

The lab, the lab is the most useful. 
39. Language skills and communication

Reading

40. comprehension Vocabulary

41. Grammar and written structures

42.

43. Grammar and written structures

44. Language skills and communication

$45 . \quad$ Reading comprehension

46. Grammar and written structures

47. Vocabulary

48.

49.

50.

51.

Grammar and written structures

Reading comprehension

Reading comprehension

52.

53.

Grammar and written structures

Grammar and written structures

$\mathrm{Vs}$

54.

$$
\begin{gathered}
\text { Vocabulary } \\
\text { Vs } \\
\text { Reading } \\
\text { comprehension }
\end{gathered}
$$

55. Language skills and communication

56. Language skills and communication

$57 . \quad$ Vocabulary
The teacher's accent and the native speakers of English in the lab.

I benefited from the reading passages and from their vocabulary.

I benefited from the grammar lessons because grammar is my problem.

No answer

Question tag questions, how to ask Yes/No questions, the way the indefinite article a is used, and the past perfect.

The lab. I was listening to natives tentatively to imitate them

I benefited from the reading passages a lot in terms of topic. I am now familiarized with reading any passage quickly.

I benefited from the differences between regular and irregular verbs and from the question tag questions.

I benefited from some of the words mentioned in the reading passage, particularly the scientific words.

Nothing new

What I benefited. Yes, the subject reminded me of the use of tenses and from the difference between the use of the articles $a$ and the.

I benefited from the reading passages and from the time given to answer questions. This familiarized me to read quickly with understanding.

I benefited from the reading passages and from the new vocabulary.

No answer

I benefited from the expressions of quantity and the tenses.

I benefited from the forms of questions, the use of articles and from vocabulary, and from the reading passages.

I benefited from the lessons given in the lab. I listened well to the native speakers of English.

The teacher was very good. Her way of speech in English was like the native speaker's. I listened well to her and I tried to imitate her.

I benefited from the new vocabulary.

No answer 
59. Grammar and written structures

60.

Grammar and written structures

61. Grammar and written structures

62. Language skills and communication

63. Language skills and communication

64. Reading comprehension

65.

66. Grammar and written structures

67. Vocabulary

68. Language skills and communication

$69 . \quad$ Reading comprehension

70.

71. Grammar and written structures

72. Grammar and written structures

73. Language skills and communication

74. Vocabulary

75. Grammar and written structures

76. Reading comprehension

77. Grammar and written structures

78. Language skills and communication

Reading comprehension

79. vs Vocabulary

80. Grammar and written structures

81.

82.
I benefited from lessons given on the tenses and articles.

I benefited from the tenses and the expressions of quantity.

I benefited from the question forms and from the progressive verbs.

I benefited from the dialogues between native speakers of English in the lab.

I benefited from the teacher's method of teaching. She gave us the chance to converse with her and with our colleagues in English.

I benefited from the reading passages. I am familiarized with reading with understanding.

No answer

I benefited a lot from the tenses and expression of quantity.

I benefited from the scientific vocabulary for my specialization.

The teacher gave me the chance to communicate in English with her and with my colleagues.

I benefited from reading comprehension passages.

No answer

I benefited from progressive verbs and question forms

I benefited from future and progressive tenses. I also benefited from the articles. I benefited from the English lab.

I benefited from some of the new vocabulary located in the end of each unit.

I benefited from the expressions of quantity, articles and tenses.

Frankly speaking, I benefited from the reading comprehension passages.

I benefited from the tenses and question forms.

I benefited from the teacher's way of speaking. This way helped me to understand what the native speakers say in the lab.

I benefited from reading comprehension passages and from vocabulary.

I benefited from the tenses and articles.

\section{No answer}

The most important thing I benefited from is the communication which took place between the teacher and students and between the students themselves. 
Grammar and written structures

83.

$$
\text { Vs }
$$

Vocabulary

Grammar and written structures

84.

85.

$$
\begin{gathered}
\text { Vs } \\
\text { Reading } \\
\text { comprehension } \\
\text { Vocabulary }
\end{gathered}
$$

86.

87.

88.

89.

90.

91.

92.

93.
Reading comprehension

Grammar and written structures

Language skills and communication

Vocabulary

Language skills and communication

Grammar and written structures

Reading comprehension
I benefited from the tenses, articles and some vocabulary words.

I benefited from the questions forms, the tenses and the reading comprehension passages.

I benefited from the list vocabulary words listed the end of each unit.

I benefited from the reading comprehension passages. The way the teacher handled these passages taught me to read the passage at first quickly and then carefully to find the main ideas included in it.

I benefited from the tenses, articles and questions.

I benefited from the lab and from the conversations between the Americans.

\section{No answer}

I benefited from the new vocabulary in the reading passages.

I benefited from the teacher's pronunciation of words and her American accent during lectures. I also benefited from the lab. I am now trying to imitate them.

I benefited from the tenses and the way questions are formed.

I benefited from the reading comprehension passages.

\section{Discussion}

The objective of this study was to explore students' expectations regarding the Remedial English course (99) and the extent to these expectations are met. This course is adopted for those who fail in the English aptitude exam in in any public university in Jordan. Based on the findings of this study, the researcher identified four main themes that the course was expected to improve and whether the students really benefited from it: Grammar, language skills and communication, reading comprehension and vocabulary.

With regard to students' expectations, findings revealed that the theme which received the highest percentage of response (59\%) is associated with language skill and communication, followed by grammar (21\%), vocabulary (11\%) and reading comprehension (9\%). The students expected that the Remedial English course would improve their communication competence through the oral and academic skills. Research highlights the importance of the four language skills and their integration for successful communication to take place. These skills should be addressed in a way that helps students meet the standards set for them and develop their communicative competence gradually. Listening and speaking are highly interrelated and work simultaneously in real-life situations. Therefore, the integration of the two aims at fostering effective oral communication. Reading and writing form a strong relationship with each other as skills. They are tools for achieving an effective written communication (Sadiku, 2015). Concerning grammar which received a logical percentage of response $(21 \%)$, students expected that this course might be able to improve their level in this area. The reason lies in the fact that using correct grammar not only helps to communicate more effectively and precisely, but also helps the learner avoid embarrassment (Bronson, 2019). Despite its importance, reading comprehension received the lowest percentage of response (9\%). Research argues that having excellent reading comprehension skills is important. It is the effectiveness and enjoyment of reading and helps not only academically, and in a person's personal life (Rutzler, 2017: 1). However, students' expectations is one of the key stones of language learning (2) and it is important to include them in the conversation about their education (LandolfI, 2014). 
AS for the aspects of language the students thought they benefited from English 99, findings showed that the theme which received the highest percentage of response (39\%) is related to grammar and written structures, followed by language skills and communication (25\%), reading comprehension (19\%) and vocabulary (17\%). Regarding grammar and written structures, the students declared that they benefited from the tenses, question forms, articles and expressions of quantity. This benefit has been highlighted by Bronson, 2019). It is argued that 'as an approach to teaching the English language, structuralism has merits. Specifically, for English learners, the basic fundamental approach to the language can make it easy to learn. The heavy focus on mechanics and proper structure make access to the language more concretely, therefore easier to learn' (LandolfI, 2014: 1). Concerning language skills and communication, twenty-two of the students stated that they benefited from both the lab and the teacher since the former gave them the chance to listen to native speakers and the latter spoke fluent English. However, the native speakers' advantages are that they have a much higher comfort level and a wider vocabulary as it includes both formal and colloquial terms. On the other hand, the non-natives have two main advantages over native speakers. Their spelling and understanding of English grammar are usually better (Ross, 2013). Although vocabulary words are regarded as an essential factor for reading comprehension, they took the least percentage of responses. That is, vocabulary represents one of the most important skills necessary for teaching and learning a foreign language. It is the basis for the development of all the other skills: reading comprehension, listening comprehension, speaking, writing, spelling and pronunciation (Essays, 2018).

The research findings obtained in this current study indicate that no remedial English language courses is completely effective or ineffective. The students considered some linguistic aspects more or less effective than the others. This does not cohere with the research findings explored in the Arab World. They showed that the remedial courses in the Arab universities had been ineffective in increasing English language skills of students (Al Othman \& Shugair, 2013). In addition, the findings obtained in the Lebanese context revealed that the remedial courses were not effective in providing better performance on academic subjects (Alghamdi \& Siddiqui, 2016, \& Nasser \& Kfouri, 2008 ). On the other hand, the findings obtained in other teaching-learning contexts indicated that that the remedial courses were effective. One finding suggested that remedial teaching was beneficial to the students' academic life (Cheng, 2014); another showed that the remedial English course raised the English proficiency of students; and a third revealed that one of the areas where students expected improvement was curricula content (Armagan, Bozoglu \& Guven, 2016).

\section{Conclusion}

The findings of this current study were limited to the setting and the participants in the study. However, it provides some important implications for EFL curriculum developers. It also encourages researchers in teaching English as a foreign language (TEFL) to conduct studies in other higher education settings to fill a gap in the literature related to student expectations and whether or not these expectations are met.

It seems that students' expectations in this study differ from their views about the degree of linguistic benefit from the target remedial course. For example, they expected that Remedial English 99 would improve their communicative skills a lot, but they found at the end of the semester that they benefited a great deal from grammar and written structures. Therefore, policy-makers, syllabus designers and practitioners should seriously take students' views into account. Moreover, researchers interested in EFL education at the university level should carry out research studies which use both interviews and classroom observation to ascertain whether the students attempt to influence the teaching-learning context according to their expectations.

\section{Acknowledgement}

I would like to give my sincere and deep gratitude to the head of language center at the Hashemite University, Dr. Bassil Mashagbeh. I would also like to thank Dr. Mai Malkawi and Dr. Mohammed Ababneh for their cooperation in the classroom.

\section{References}

Alghamdi, F., \& Siddiqui, O. (2016). Supporting Low-Achieving EFL Learners: Expectations, Procedure and Significance of Remedial Session at a Saudi University. Journal of Education and Training Studies, 4(12), 204-212. https://doi.org/10.11114/jets.v4i12.2028

Al-Jamal, D.A., \& Al-Jamal, G.A. (2014). An Investigation of the Difficulties Faced by EFL Undergraduates in Speaking Skills. English Language Teaching, 7(1), 19-27. https://doi.org/10.5539/elt.v7n1p19

Al Othman, F.B., \& Shugair, K.M. (2013). Effectiveness of the Remedial Courses on Improving EFL/ESL Students' Performance at University Level in the Arab World. International Journal of Higher Education, 2(3), 132-138. https://doi.org/10.5430/ijhe.v2n3p132 
Armagan, O. Bozoglu, O., \& Guven, E. (2016). EFL Students' Expectations in Higher Education Level English Preparatory Schools in Turkey. International Journal of Sciences: Basic and Applied Research, 30(40), 182-192. http://gssrr/org/index.php?jounal=Journal Of Basic And Applied

Bronson, S. (2019). Importance of Correct Grammar. The classroom. com/importance-correct-grammar-6523732

Cheng, C.M. (2014). Individual Differences: How Remedial Teaching Transforms Low-Achievers when Learning English. Journal of Modern Education Review, 4(11), 859-877. http://www.academicstar.us. https://doi.org/10.15341/jmer(2155-7993)/11.04.2014/001

Essays, U.K. (2018). The Importance of Teaching and Learning Vocabulary English language essay. Retrieved from http://www.ukessays.com/essays/english-language/the-importance-of-teaching-and-learning-vocabulary-english -language-essay-php?vref=1

Forstall, M. (2019). The Structuralist Approach in Teaching English. The Classroom. Com/structural-approach-teachingenglish-652382

Jimenez, P.K. (2017). Exploring Students' Perceptions about English Learning in a Public University. How, 25(1), 69-9. https://doi.org/10.19183/how.25.1.385

LandolfI, L. (2014). Students' of English at University: Awareness, Expectations and Failure Issues. Frontiers of Language and Teaching, 5, 110-123. academia.edu./6888485

Mc Daniel, R. (2018). The Advantages of Remedial Activities in the classroom. classroom.synonym.com/definition-reading-intervention-6166835.html

McDonald, A., Newton, P., Whetton, C., \& Benefield, P. (2002). Aptitude Testing for University Entrance: A Literature Review. Sutton Trust, 1-83. http://www.suttontrust.com/wp/uploads

Nasser, R.N, \& Kfouri. C.A. (2008). Assessment of the English Remedial Programme at a Private University in Lebanon. Researchgate. http://www.researchgate.net/publication/237771406

Ross, J. (2013). English Teachers-Native or None-Native English Speakers? EBC TEFL Courses. ebcteficourse.com/blog/native-or-non-native-english-speaker/

Rutzler, S. (2017). Importance of Reading Comprehension. Math Genie in the News. Mathgenie. $\mathrm{com} / \mathrm{blog} /$ importance-of-reading-comprehension-in-high-school

Sadiku, M. (2015). The Importance of Four Language Skills Reading, Speaking, Writing, Listening in a Lesson Hour. European Journal of Language and Literature Studies, 1(1), 29-31. journals.euser.org. https://doi.org/10.26417/ejls.v1i1.p29-31

Siddiqui, O., \& Alghamdi, F. (2017). Implementing Differential Instruction in EFL Remedial Classes: An Action Research. Education and Linguistic Research, 3(3), 89-100. https://doi.org/10.5296/elr.v3i2.11726

Swallow, E. (2016). 10 Student Expectations that all Schools should Consider. Education Reform. nobleimpact.org/2016/05/13/student-expectations=of-school/ 